PART ONE

Partition and the Cost of Statehood 



\title{
The Political Economy of State Formation in Palestine
}

\author{
Adam Hanieh
}

The question of state formation in Palestine has attracted a great deal of attention from scholars and activists alike since the establishment of the Palestinian National Authority (PNA) in 1994. Much of this debate has focused upon questions about three matters: (1) the relationship between peace and "state-formation", (2) the priorities and nature of Palestinian Authority institution-building, and (3) the linkages between donor funding and the emerging features of Palestinian government. Given the nature of the Oslo Accords and subsequent negotiations between Israel and the Palestine Liberation Organization (PLO), the discourse surrounding these debates has tended to be based almost exclusively on some version of a "two-state" solution-typically with greater attention given to the West Bank as the spatial center of PNA institution-building.

The aim of this chapter is to present a critique of this state-formation literature, focusing in particular on the analytical silence it shows concerning the wider political economy of the Middle East region as a whole. I argue that much of the debate around Palestinian state formation tends to a methodological perspective that views Palestinian society in the Occupied Palestinian Territories (OPT) - and in the West Bank specifically - as a self-contained social formation in which statecivil society relations are implicitly assumed to exist as separate and distinct from the wider region. In this sense, state-formation literature is typically characterized by a form of methodological nationalism, in which the territorial borders of the national state-or the Palestinian state-in-formation-are considered as the exclusive vantage point from which to understand the various modalities of state-building. ${ }^{1}$ This is not to deny that much of the literature considers the impact of various trade and financial relationships between a future Palestinian state and neighboring countries. The point, however, is that these relationships are considered as external to Palestinian social formation as such. It is the contention of this chapter that it is necessary to consider the ways in which the developmental tendencies of 
the regional scale already exist internal to Palestinian social formation. Without considering the ways that these regional processes have been internalized into the nature of Palestinian state and class formation under the PNA, it is not possible to accurately assess the likelihood of any state-building trajectories over the coming period (including both one- and two-state options).

The chapter is divided into two main parts. The first begins with a survey of the general state-building literature as expressed in the policies of international agencies and government donors. This literature has identified three supposed characteristics of "successful" states-authority, legitimacy, and capacity-and aims to develop these features through technical support and financial aid. The section then concretizes these formulations in the Palestinian context, looking at both the dominant approach towards state-building in Palestine and the criticisms that have been raised against this within the literature. The final part of this section presents a reexamination of the state-formation debate (both generally and in Palestine) based upon a critique of the way that much of this literature conceives of the state itself at a theoretical level. In counterposition to the neo-Weberian understanding of the state that dominates most state-formation discussions, this section puts forward an alternative conception of the state based upon an understanding of the prevailing social and power relations that exist under capitalism.

The second part of the chapter aims to build upon this alternative conception of the state to assess how the regional context has determined the character of state formation in Palestine. In this vein, I present an overview of Palestine in the regional context, and the ways in which global relations of power have shaped the nature of the state-building project in Palestine. I also look at the implications of these regional trajectories for the nature of Palestinian class and state formation, arguing that the particular social base of the PNA has come to rest upon a business class that is largely drawn from a layer of Palestinian diaspora capital-one that has been fully integrated into the modalities of state formation under the PNA. The concluding section examines what this particular class-state structure means for the possible future trajectories of Palestinian self-determination.

\section{THE STATE FORMATION DEBATE}

\section{Authority, Legitimacy, Capacity}

The explosion of the state-building literature through the 1990s and 2000s was closely related to two important developments in the global political economy at the time. The first of these was the emergence of the neoliberal economic paradigm as the virtually unchallenged policy model. This framework promoted market liberalization and deregulation, and the opening up of economies to cross-border trade and finance. Closely connected to the breakup of the Soviet Union and the emergence of newly independent states across Europe and Central Asia-the socalled "transition economies" - this new era of neoliberal globalization raised a 
series of questions about how best to move from centrally planned, bureaucratic economies to market-based systems of accumulation. At the same time in the South, a range of conflicts and wars across numerous countries-notably Somalia, Iraq, Afghanistan, the Democratic Republic of Congo, and Sudan-placed the issue of rebuilding apparently dysfunctional state systems firmly on the map of international institutions and development practitioners.

These trajectories of neoliberalism and conflict were to shape the content of the emerging state-building debate, which crystallized around two key theoretical propositions. The first of these was the linkage between "democratization" (or "democracy-promotion") and neoliberal models of development. The creation of liberal democracies and market-based economies were said to be mutually reinforcing processes that offered the best guarantors for stability. In Europe, newly established institutions such as the European Bank for Reconstruction and Development (EBRD) consciously twinned the rebuilding of former Eastern bloc states with free-market principles, providing loans and grants to promote the privatization of infrastructure and industry. Elsewhere, notably in the Middle East, the US government was to launch a policy framework based on what George W. Bush described in 2004 as "free elections and free markets." The initial testing-ground for this policy was post-2003 Iraq, where the US government stated they sought to see a narrow form of liberal democracy that could provide legitimacy for freemarket economic measures. Accompanying this policy turn, a host of quasigovernmental institutions such as the US National Endowment for Democracy (NED), the National Democratic Institute (NDI), the International Republican Institute (IRI), the Center for International Private Enterprise (CIPE), and the Solidarity Center were to employ the same basic argument linking "free markets" and "a vibrant civil society" with the new state-building emphasis.

The second key theoretical proposition of the state-building literature was the explicit argument that effective state building was causally related to more peaceful states. This "liberal peace" perspective claimed that "conflicts could be defused by encouraging the liberalization of the political and economic structures of postconflict societies." If a state were governed along liberal democratic lines, it would be less likely to go to war because of the inherent reluctance of the population to engage in military conflict. "Democracies," as one perceptive critic of the liberal peace paradigm noted, "do not go to war with one another." Through the 1990 s and 200os, this perspective was supplemented with further arguments-both theoretical and empirical - that intra-state violence was also less likely to occur within liberal democracies. ${ }^{5}$ Francis Fukuyama, for example, was to link state weakness to a long list of internal crises, claiming that "weak or failing states commit human rights abuses, provoke humanitarian disasters, drive massive waves of immigration, and attack their neighbors." ${ }^{\prime 6}$ Likewise, the World Bank would explain the rationale behind its State and Peace Building Fund as one in which building states and building peace are considered as complementary processes.? 
Nonetheless, beyond the emphasis on neoliberal economic models and the claims around peace, the question of state-building raises a range of related theoretical and practical issues. What is meant by state building in practice? How is the state conceived of theoretically, and what particular institutional features characterize a successful state? What is the most appropriate temporal sequencing for the process of building state institutions? What actors should drive this process? Although there exists a wide variety of specific approaches to these questions, the starting point for the vast majority of relevant literature is an ideal-type definition of the state drawn from neo-Weberian sociology. ${ }^{8}$ According to this perspective, a state is defined through its "monopoly of the legitimate use of physical force within a given territory." ${ }^{\prime 9}$ Flowing from this definition, there are three supposed features of all states that are typically highlighted across the literature:

1. Authority, defined as "the ability of the state to project its political power over all its territory, to reach all citizens regardless of their location, to maintain law and order and protect citizens from predation and violence. It is the ability of the laws and rules of the state to trump all other laws and rules."

2. Capacity, or "the ability of the state to deliver or procure goods and services, design and implement policies, build infrastructure, collect revenue, dispense justice, and maintain a conducive environment for the private sector."

3. Legitimacy, or "whether citizens feel the government has the right to govern-and whether they trust the government." ${ }^{10}$

Each of these three features is postulated to be interrelated to the others and self-reinforcing. Successful states are able to enforce authority over their populations within a defined territory, and this helps to sustain their legitimacy. But authority stems not only from the use (or threat) of violence, but also from the generalized belief of the subject population in the legitimacy of the state's right to act as the supreme monopoly of force. In turn, this legitimacy arises from the state's capacity to ensure that needs such as security, stability, and provision of basic services are met.

Successful states are therefore characterized by the right balance of this interconnected triumvirate-authority, legitimacy, and capacity. When this balance does not exist, a state is said to be in crisis. As the United States Agency for International Development (USAID) was to put it in the mid-20oos, such states are defined by a "central government [that] does not exert significant control over its own territory or is unable or unwilling to assure the provision of vital services to significant parts of its territory where legitimacy of the government is weak or non-existent, and where violent conflict is a reality or a great risk." ${ }^{11}$ By assessing states' relative degrees of authority, legitimacy, and capacity, academic and development research attempted to correlate gaps in one or more of these attributes with what were described as weak, fragile, fragmented, or stressed states. 
Throughout these debates, the case of Palestine and the Palestinian National Authority has provided a prominent laboratory for these theoretical claims. Large levels of donor funding have gone towards building the institutions of the Palestinian National Authority since its establishment in 1994. In many ways, as numerous government and donor reports have noted, the PNA's institutional capacity has consistently been viewed as an international exemplar in relation to statebuilding. ${ }^{12}$ Moreover, given the ongoing reality of Israel's occupation, Palestine also remains a key focus of the debates around "peace-building" and state formation. In this respect, it is instructive to turn to how these state-formation debates have unfolded in the Palestinian context.

\section{State-Building in Palestine}

The debates around state formation in Palestine are closely linked to an assessment of the negotiations process between Israel and the PLO that began in the early 199 os with the Oslo Accords. Drawing upon the "liberal peace" theory, the creation of a functioning Palestinian state was portrayed as means of fostering a successful peace process-typically understood through the lens of guaranteeing Israel's security. A particularly significant role in this was played by the World Bank, which issued its influential six-volume study, Developing the Occupied Territories: An Investment in Peace, in early 1993, laying out "a path to reforming, reorganizing and stabilizing the OPT's economic and social balance ... and preparing its economic integration into the broader set of regional neoliberal interests." ${ }^{\prime 3}$ According to one critic, the logic essentially came down to the argument that "building a democratic Palestinian state would buttress the peace process." 14 The European Union was a prime advocate of this approach, arguing in its 1999 Berlin Declaration that it was "convinced that the creation of a democratic, viable and peaceful sovereign Palestinian state ... would be the best guarantee of Israel's security."15

Based on this perspective, and drawing heavily from the wider theoretical literature outlined above, donor support to the PNA since the mid-199os has focused on building the institutional elements of the PNA's capacity and authority. Following the end of the Second Intifada in the early 2000s, the death of Yasser Arafat in 2004, and the split between the West Bank and Gaza Strip in 2006-leading the PNA to become largely territorialized in the West Bank-this orientation was codified in the November 2007 Palestinian Reform and Development Plan for 2008-2010 (PRDP). Written with the assistance of the World Bank and other IMF advisors, the PRDP became the guiding framework for Palestinian development policy, particularly in the West Bank areas where the PNA was well established. In many ways, the PRDP explicitly confirmed the neoliberal orientation of state-building highlighted above. It committed the PNA to undertaking a series of fiscal reforms aimed at reducing public expenditure on public sector wages and employment, as well as supporting private sector-led development of key sectors such as housing, infrastructure, and industry. The overall goal was to 
reach a "diversified and thriving free market economy led by a pioneering private sector that is in harmony with the Arab world, [and] is open to regional and global markets." ${ }^{16}$ External donor funding to the PNA was linked to its implementation, and these flows were to be controlled through a dedicated bank account managed by the World Bank.

The other aspect of PNA state formation that was heavily promoted as part of the PRDP and other donor assistance was security. Connected explicitly to the notions of state "authority" and "peace through state-building," security expenditure was to become a major focus of foreign support. Essential to this was the reconstitution and unification of PNA security forces through the open financial and logistical support of Western military and intelligence agencies. The PNA security budget was allocated the largest portion of all funding in the PRDP (257 million dollars), with money going to the training of new police and intelligence forces as well as the construction of new prisons. A US Army officer, Lieutenant General Keith Dayton-fresh from his position as head of the search for alleged "weapons of mass destruction" in Iraq, following the 2003 US-led invasionserved as the key point person for the training of Palestinian police from 2005 to 2010. Headquartered in Tel Aviv and supported by British, Canadian, and Turkish personnel, Dayton's mission involved running two training compounds in Jordan and the West Bank for Palestinian security forces. ${ }^{17}$

In this manner, PNA state formation was largely conceived through a technocratic lens, with a focus on building the (neoliberal-oriented) capacity of state institutions, and developing the "monopoly of violence" within the territories administered by the PNA (understood, as noted, through the perspective of ensuring Israeli security). These themes-encapsulating the authority and capacity features of the state-building theory-were strongly supported by US and EU policymakers, institutions such as the Quartet, the World Bank and the International Monetary Fund (IMF), as well as nongovernmental donor organizations.

Despite the uniformity in international support for this model of state-building, a number of important studies have raised significant critiques regarding donor approaches to state-building in Palestine. ${ }^{18}$ One early influential critique of the dominant approach to state formation in Palestine has been offered by Mushtaq Khan. Echoing a shift in the focus of state-building discourse towards the question of legitimacy, Khan has highlighted the problematic nature of donor support for the PNA's technocratic capacities-in which emphasis is placed on the effectiveness and viability of state functions rather than popular endorsement of PNA rule. ${ }^{19}$ Identifying a two-way relationship between what he describes as state functions and state legitimacy, Khan notes three possible feedback routes through which these two variables could potentially impact one another. First, state legitimacy is partially dependent upon the provision of functions by the state. In the case of the PNA, this has been the traditional focus of donor assistance, which has consequently emphasized the building of the technical and bureaucratic 
capacities of the state-in-formation. Secondly, however, Khan notes that the choice of what functions are provided is inherently a political one-if certain functions are prioritized over others, and these do not correspond with the "distribution of political values, organizations and aspirations in a country," then the legitimacy of the state is likely to be undermined. ${ }^{20}$ In the case of Palestine, Khan argues that this process of prioritization has largely been determined by external powers and has traditionally focused upon the provision of security guarantees to the occupying power and a developmental model that reflects the concerns of foreign interests. Finally, a third possible feedback route is the impact that declining legitimacy has on the viability of the state itself. If a state lacks legitimacy, according to Khan, then it becomes more and more difficult for it to provide the requisite services. What may ensue is a vicious cycle, in which declining legitimacy fuels declining ability to provide functions, leading to further declines in legitimacy. ${ }^{21}$

Similarly, other scholars have focused on the contradiction between attempting to build "normal" state institutions in the context of an ongoing-and deepening-Israeli occupation. ${ }^{22}$ As the International Crisis Group noted in 2002, for many Palestinians, "the idea of modernising the PNA and instruments of governance-while under military occupation is either impossible or meaningless." ${ }^{23}$ Precisely because the PNA was established with the prioritization of Israeli security in mind, and with its sovereignty and extent of authority contingent on fulfilling this task, it "might be more accurately characterised as an extension of the Israeli security apparatus." ${ }^{24}$ As Mandy Turner put it in her analysis of Hamas' electoral victory in 2006, "we are, at present, witnessing the problems inherent in a peace process which created an institution, the PA, whose primary task was to deliver security to a powerful neighbour who retained control over PA borders and economy. This task ... is in contradiction to promoting the development of a sovereign and democratic Palestinian state-a process that is dependent upon a resolution of the conflict and the end of Israeli occupation." ${ }^{25}$

In this context, flows of aid to the PNA take on a particularly pernicious role, as they are "mostly geared toward enhancing, if not engineering, the legitimacy of the PNA in the West Bank within the straightjacket imposed by the Oslo peace process and in accordance with the exigencies of the Israeli occupation." ${ }^{26}$ Because "the real obstacles to the economic development of the territories were not weak institutions but instead the intensifying occupation-related elements which donors were refusing to deal with," donor activity served to depoliticize the occupation itself. ${ }^{27}$ In this sense, Israeli settler-colonialism comes to be seen as a question of administrative regulations that may potentially constrain Palestinian development (or indeed, assist it), rather than as a form of power that necessarily penetrates all aspects of Palestinian society. ${ }^{28}$ The technocratic approach towards state-building thus involves an elision of power relations, which leads to the incorporation of Israeli colonialism into the process of development itself. ${ }^{29}$ In short, the pacification of the Palestinian population, rather than any genuine concern 
with Palestinian self-determination or conditions of life in the OPT, becomes the primary goal and result of Western (and Israeli) policy. ${ }^{30}$

All of these critiques make important contributions to unpacking the supposed neutrality of the dominant approach to Palestinian state-building and revealing the relations of power that continue to structure development options in the area. Yet while this literature stresses the ongoing reality of Israeli occupation and its relationship to the politics of the PNA, it is a contention of this chapter that the problem with the dominant literature is a broader one, which lies in its theoretical conception of the state. Specifically, the neo-Weberian understanding of the state is itself flawed, in that it constructs an ideal-type of the state that is premised on an artificial separation between "state" and "society" (or "politics" and "economics") and thus abstract the power relations-particularly those of class-that necessarily typify all capitalist societies, from its analysis of the state and state-building.

\section{Rethinking State Theory: Alternatives to Neo-Weberianism and Neoliberal Approaches}

Hugo Radice has noted the relationship between much of the general stateformation literature and the "developmental state" approach that was popularized in the 1980 o and 1990 s during the so-called East Asian miracle. ${ }^{31}$ The latter explains the impressive growth rates of countries such as South Korea, Taiwan, and Japan on the basis of the supposed autonomy of their states, which was said to enable a balance of contending social interests and well-coordinated government-led policies prioritizing growth and domestic industrial development. In this sense, both sets of literature share a neo-Weberian conception of the state, rooted in liberal ideology that thinks of the state as "as a public realm separate from the private realm of civil society." ${ }^{2}$ The core assumption is a conception of the state as an autonomous body that stands above social relations, with its primary function the facilitation of markets and the rule of law.

Against these neo-Weberian perspectives, Radice and numerous other critics have argued that the state, as an institution, is never and cannot be neutralrather, it should be understood as a "form of appearance" of the social relations that constitute society. The state is an institutional form of these social relations, one which acts to maintain the existing class structure, mediate the conflicts that inevitably appear between and within classes, and allow these relations to reproduce themselves. ${ }^{33}$ The apparent neutrality of the state and its separation from society is thus ideological-acting to conceal the relations of power that underlie all capitalist social formations. ${ }^{34}$ Although the state may really appear to us in this neutral form, we need to penetrate below this appearance to grasp the state as a social relation, which, in the words of the philosopher Bertell Ollman, constitutes a "set of institutional forms through which a ruling class relates to the rest of society." ${ }^{35}$ The state is not an independent, distinct sphere, severed from the social structure that generates its character, rather "state and society are interdependent and interpenetrate in a multitude of different ways." ${ }^{36}$ 
Seen in this manner, the separation between politics (embodied in the state) and a supposedly independent civil society (encompassing the market) is illusoryeven as a normative goal. Academic approaches that present the ideal of liberal democracy as the desired policy end-supposedly guaranteeing the same rights and responsibilities for all "civil society actors" regardless of wealth, social status, or accident of birth-act to obscure the reality of social power that is foundational to the ways that markets work. These approaches abstract the real, substantive differences of power among individuals due to their socioeconomic role, that is, their class position, instead positing individuals as equal citizens with the same rights and responsibilities vis-à-vis the state. Within these neo-Weberian conceptions, markets are also neutralized, seen as instruments of "resource allocation rather than exploitation. ${ }^{37}$ As a result, much of both the developmental and state-formation literature wields concepts such as "governance," "civil society," and "participation" in a principally obfuscatory manner- "deflect[ing] the citizen from class identification in favour of a contractual relationship with the state," while simultaneously, "the representative-politics component of the relationship has been largely reduced to a circulation of political elites through a banal and etiolated electoral form of democracy." ${ }^{38}$ By treating the state as a disconnected and neutral "thing" rather than as a relation formed alongside the development of social structures, the dominant state-building literature treats the institutional forms of society as determinant rather than determined. ${ }^{39}$

The implications of this perspective for understanding state-formation in Palestine are two-fold. First, it allows us to penetrate the ideological form contained within the standard themes of authority, capacity, and legitimacy that dominate Palestinian (and the wider) state-building literature. While these features may indeed be necessary functions that all states perform, they are nonetheless functions of capitalist states (about this, the normative, market-oriented prescriptions of state-building literature are unequivocal). To pose these categories as if they can be understood in the abstract-or through undifferentiated aggregates such as "the people" or "the national interest"-only serves to conceal the ever-present relations of power. Instead, we should ask questions like: Authority-in whose hands? Capacity - to do what, and in whose interest? Legitimacy-in whose eyes? If the state is not, in fact, a neutral, distinct sphere then these questions are necessarily presupposed; to posit them in their abstract, general form only serves to disappear power itself.

Secondly, approaching the state through the social relations that produce its particular forms means that it is necessary to map these relations of power in their entirety. In the case of Palestine, this is clearly inseparable from the settler-colonial character of the Israeli state, as the critical literature surveyed above affirms. To treat Palestinian state-building as a technical exercise of authority, capacity, and legitimacy that can be achieved in partnership - or at least within and alongsidean ongoing colonial occupation acts again to disappear power relations. But the critical literature, in this respect, does not go far enough. It is the contention of this 
chapter that it is necessary to view Palestinian social relations in their regional context-to understand the way that class formation under the Palestinian National Authority is deeply interpenetrated with the regional political economy. This can tell us a great deal about the state-building project as it currently is framed, as well as the obstacles to alternative models of state formation.

\section{SITUATING PALESTINE IN THE REGIONAL CONTEXT}

Central to any understanding of the Middle East is an appreciation of the region's insertion within the global economy and its role in shaping the architecture of international power relations. In this respect, there are two interlinked dynamics that have shaped the region's development since the early twentieth century. The first of these is the fundamental place of hydrocarbons-oil and gas-in powering global capitalism. Oil and gas came to underpin the shifts in global production chains in the post-World War II era, constituting a strategic commodity that fueled industrial, transportation, and military networks, and formed the feedstock of petrochemical products such as synthetic rubbers, plastics, and fertilizers. ${ }^{40}$ Through the postwar period, the Middle East-notably the oil-rich region of the Gulf Arab states-became the core global supply source for the extraction and export of relatively cheap and accessible hydrocarbons. Simultaneously, the sale of these hydrocarbons facilitated the flow of large amounts of capital, which came to be known as petrodollars, into the Gulf. The redirection of these petrodollar surpluses into US and European financial markets was a vital feature of the way that the architecture of global finance developed through the 1960s and 1970s, helping to underpin the reserve status of the US dollar as well as the emergence of debt and other financial markets through these decades. ${ }^{41}$ In the context of these two interrelated dynamics of oil and finance, foreign domination of the region constituted a key strategic element to the balance of rivalries between different global powers; this was particularly significant with the shift from a largely European-centered colonial system to an international state system structured around US hegemony in the postwar period.

These global issues intersected with local, regional dynamics-most notably the various anticolonial and nationalist movements that emerged through the 1950 os and 196os in countries such as Egypt, Yemen, Algeria, Syria, and Iraq. As new governments came to power in these states, they attempted to pursue statist forms of development that prioritized domestic control of industry, the provision of social services backed by food and fuel subsidies, the expansion of higher education, and the guarantee of employment to university graduates within growing public sectors. These policies led to an improvement in living conditions for much of the region's population, but they were also characterized by repressive forms of rule aimed at curtailing any independent political action. ${ }^{42}$ In response to these developments, Western governments-led by the United States-sought to roll 
back the growing independence movements in the region. At the political level, this was pursued through the consolidation of alliances with three main regional allies: Saudi Arabia, Iran, and Israel. Financial and military aid to these three countries helped to strengthen their positions within regional hierarchies, and, in return, these states moved to confront and undermine the nationalist or left-wing movements that were growing in influence across the Middle East.

Israel played a particularly significant role in this process. Because it had emerged as a settler-colonial state founded upon the expulsion of around threequarters of the original Palestinian population, Israel depended upon foreign support for its ongoing viability and the maintenance of its ethno-religious character as a self-defined Jewish state. ${ }^{43}$ In this sense, it was a much more reliable partner of foreign powers than Arab regimes that faced ever-present pressure from their own citizen populations. Following the 1967 war, in which the Israeli military dealt a devastating blow to Arab nationalist regimes in Syria and Egypt-and expanded its occupation of Arab land to the West Bank, Gaza Strip, (Egyptian) Sinai Peninsula, and (Syrian) Golan Heights - the United States became the country's key patron, supplying it annually with billions of dollars' worth of military hardware and financial support. Indeed, one former US intelligence officer has been quoted as claiming that the US-Israel military relationship was worth "five CIAs" and that upkeep of an armed force equivalent to Israel's in the Middle East would cost US

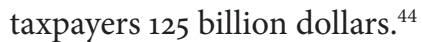

In the wake of these military defeats-soon followed by the global economic recession of the early 1970s, and the subsequent erosion of Arab nationalist regimes-the door was opened for the reconfiguration of the regional political economy. Through the latter part of the 1970s and 1980s, virtually all Arab governments began laying the ground for a range of structural adjustment packages that embodied the basic precepts of neoliberal reform. Most notably, this involved the dismantling of collective and state property rights in land, the beginnings of privatization and cut-backs to the state sector, and opening up to foreign trade and financial flows. Although the pace of these changes varied considerably across the region, by the early 1990 s most Arab states had made significant steps along this new path. ${ }^{45}$

The changes during this period coincided with-and were closely connected to-the rise to prominence of the state- and peace-building literature surveyed above. The cases of Iraq and Palestine were the two central foci of this policy shift in the Middle East. In Iraq, the themes of democracy promotion, regime change, and state-building adumbrated the devastating decade-long sanctions regime imposed on the country in the 1990s and the US/British-led invasion of 2003, which led to the overthrow of Saddam Hussein and the establishment of a new US-led Coalition Provisional Authority. Simultaneously, the Palestinian Authority was formed in 1994 as part of the Oslo peace process discussed above. These political developments were accompanied by a rearticulation of both US and EU policy 
towards the region itself. In the case of US policy, hegemony over the Middle East continued to center upon alliances with Israel, the Gulf states, and client regimes such as Egypt and Jordan (the strategic link with Iran was broken with the 1979 revolution). There was a change, however, in how these alliances were conceived. Most importantly, through the 1990s and 2000s, US policy shifted towards the explicit aim of developing closer political and economic ties between these three pillars of support within the region. Articulated under the concept of "the New Middle East," the policy sought to tie these different zones together within a single economic zone. To do so required the dropping of Arab boycotts towards Israel and the development of joint investments and other economic projects. "Normalization" of Israel's ties with Arab states thus became a central focus of US policy in the region. ${ }^{46}$

In this respect, the Oslo negotiations were an important feature of integrating Israel into the region. Most significantly, Oslo would provide a Palestinian "green light" for Arab normalization with Israel. For Israel, this process would also enable a shift in its own economic orientation. Following an economic crisis in 1985 the Israeli economy had moved towards high-value added exports connected to development of information technology, pharmaceuticals, and military industries. Growth in these sectors was enabled by US financial support-indeed, for many decades Israel had been the recipient of US aid without the conditions that were tied to loans made to Arab states. Moreover, since the signing of a US free trade agreement with Israel in 1985, the United States had run a significant trade deficit with Israel. In this context, the attempt to normalize Israel's relations with other Arab states would further facilitate the internationalization of Israeli capital itself-allowing foreign investors to invest in the country without fear of Arab boycotts and marking the expansion of Israeli companies through core stock markets in the United States and European Union. ${ }^{47}$

Between 1994 and 1998, a series of intergovernmental summits known as the Middle East and North Africa (MENA) Economic Summits codified this trend towards normalization. The first of these, held in Morocco in 1994, saw concrete steps towards the lifting of regional economic boycotts and the establishment of a Middle East-wide chamber of commerce. Then-US Secretary of State Warren Christopher was to note that "the Middle East is open for business . . . the conference could be the beginning of a beautiful friendship." 48 Subsequent MENA summits in Cairo and Amman explicitly tied normalization with the deepening of neoliberal reform processes, including - as the Cairo conference final resolution noted- "privatisation, structural reform, and removing trade barriers" which were said to provide "for a more business-friendly economic climate throughout the region." ${ }^{49}$

One important indication of these regional shifts was the establishment of qualified industrial zones (QIZ) in Jordan and Egypt. QIZ provided duty-free access to US markets for Jordanian and Egyptian exporters, provided that a certain 
percentage of inputs were from Israel (8 percent in the case of Jordan, 11.7 percent in the case of Egypt). Launched in 1997, these QIZ perhaps best symbolized the new era of normalization between Arab capital and Israel. In 2004, Egypt also launched its first QIZ in an agreement with Israel and the United States. Six more QIZs were approved in subsequent years, and from 2005 to 2008 exports from these zones grew at an annual average rate of 58 percent, ten times that of total exports from Egypt to the United States. ${ }^{50}$ Since their establishment, they have come to dominate bilateral trade between the United States and Jordan and Egypt respectively. In 2007, the US government was reporting that exports from the thirteen QIZs established in Jordan accounted for a massive 70 percent of total Jordanian exports to the United States. ${ }^{51}$ In 2008, close to one-third of Egypt's total exports to the United States came from QIZs. ${ }^{52}$ By 2013, this figure had risen to nearly 50 percent. ${ }^{53}$

Despite the eruption of the Second Intifada in 2000, the orientation towards normalization, neoliberal reform, and the strengthening of US influence in the region continued to deepen. In mid-2003, George W. Bush announced the US aim to establish a Middle East Free Trade Area (MEFTA) by 2013, which was envisioned as encompassing the region from North Africa to the Gulf. The means to achieving this free trade area were a range of bilateral economic agreements between the United States and individual Arab states, eventually joined together within a single zone. Importantly, these free trade agreements contained clauses that committed these states to lift any boycotts on Israel. Pointedly, they were also connected within US government discourse with the "democratization" discourse described earlier. Robert Zoellick, for example, who acted as US trade representative in the early 2000 s, was to note that the goal of this regional trading bloc was "to assist nations that are ready to embrace economic liberty and the rule of law, integrate into the global trading system, and bring their economies into the modern era." ${ }^{54}$ Although MEFTA ultimately proved unable to reach its goal of establishing a regional free trade area, it did lead to four new free trade agreements with countries in the Middle East: Bahrain, Jordan, Morocco, and Oman. Prior to MEFTA, the only bilateral free trade agreement the United States held in the region was with Israel, completed in $1985 .{ }^{55}$

In parallel to these US trade agreements through the 1990s and 200os, the European Union also sought to deepen its influence in the region. In this case, the focus was on countries surrounding the Mediterranean, reflecting the longstanding economic ties between Europe and North Africa in particular. The European Union's moves in this direction, like those of the United States, have promoted liberalization of economies and normalization with Israel. These goals were initially expressed in the Euro-Mediterranean Partnership (EMP), also called the Barcelona Process, which was established in 1995 with representatives from Algeria, Cyprus, Egypt, Jordan, Israel, Lebanon, Malta, Morocco, the PNA, Syria, Tunisia, and Turkey. The Barcelona Process aimed at creating "open economies 
by the opening-up of markets . . . [and] the elimination of trade barriers." ${ }^{56}$ This would include a focus on "fiscal, administrative and legal reforms as well as deregulation of public services ... in order to raise the level of foreign direct investment in the southern Mediterranean economies." ${ }^{57}$ Following the establishment of the EMP, the European Union moved to sign a range of individual treaties, known as association agreements, with Mediterranean countries. ${ }^{58}$ These association agreements required EMP countries to liberalize trade and domestic markets in order to receive access to financial aid and European export markets.

In the wake of these internationally driven restructuring processesaccompanied by the increased engagement of international financial institutions in the development of Arab government economic policy-was a pronounced deepening of neoliberal reform processes throughout the 2000s. By 2009, the Middle East as a whole was acclaimed by the World Bank as the region with the second greatest jump in liberalization measures of any in the world-seventeen out of nineteen countries recorded advances in this regard. This was most clearly marked in Egypt where the so-called "government of businessmen" of the mid-20oos won plaudits from the World Bank and other international institutions; but, more generally, Arab governments moved decisively in this period towards adopting policies such as privatization, labor market deregulation, and opening up to trade and financial flows. Importantly, however, this extension of neoliberalism did not only involve shifts in national economic policy. Accompanying these trends, large Arab conglomerates-most notably those based in the Gulf region-utilized market liberalization to expand their own regional activities. This internationalization of largely Gulf-based capital-facilitated by the rapid rise in oil prices (and hence surplus capital) from 2000 to 2008-meant that class structures within individual Arab states became increasingly imbricated with ownership structures involving Gulf investors. ${ }^{59}$ This is partially indicated by figures on foreign direct investment (FDI) flows originating in the Gulf, notably to the Mashreq subregion: indeed, from 2003 to 2010, Gulf investments made up 75 percent of total FDI inflows for Lebanon, 69 percent for Jordan, 61 percent for Syria, 59 percent for Egypt, and 46 percent for Iraq. ${ }^{60}$ These capital flows were especially marked in the real estate, financial, telecommunications, and retail sectors-but also involved the extension of Gulf-based ownership of logistics, manufacturing, and industrial assets.

This particular feature of the regional political economy has critical implications for understanding Palestinian state formation as it is currently conceived. From 2003 to 2008, more than two-thirds of total global FDI projects announced in PNA-controlled areas originated in the Gulf region. ${ }^{61}$ These figures are a tiny proportion of total Gulf-origin FDI in the wider region (less than 1 percent), but for the Palestinian economy they are substantial. Moreover, they do not capture other important Gulf capital flows to the PNA-including budgetary support, development loans, and portfolio investment in the Palestinian stock market. 
It is necessary, however, to conceptualize the internationalization of Gulf capital in a wider sense than simply FDI flows. Most significantly, internationalization has occurred through the "return" to Palestine of diaspora Palestinian groups who are headquartered or largely based in neighboring countries (particularly Jordan and the Gulf). Two prominent examples are the Al Masri and Khoury family groups, both of whom locate their origins in pre-1948 Palestine. The initial capital accumulation of these groups was closely connected to state formation in the Gulf states, through the establishment of companies involved in the laying of pipelines, engineering and construction, and the provision of services to the Gulf's oil and gas industries. Since that time, the original companies founded by these family groups have expanded across the Middle East, but a key zone of their accumulation remains located in the Gulf. Following the signing of the Oslo Accords and the establishment of the PNA in the 1990s, this diaspora capital became integral to the development of the new Palestinian economy in the West Bank and Gaza Strip. This took place through direct investments and the establishment of subsidiaries in the OPT, as well as through the formation of an important network of holding companies that linked this diaspora class to state capital (ultimately funded through foreign aid to the PNA) and local elites.

The outcome of these cross-border ownership ties linking the diaspora and the local Palestinian market has been an economy largely dominated by Palestinian capital groups based in the Gulf, as well as Gulf investors. In banking and finance, for example, such groups directly control fifteen out of the seventeen banks in operation in PNA-controlled areas. ${ }^{62}$ These include the three most important banks (the Bank of Palestine, the Arab Bank, and Cairo Amman Bank), which between them operate nearly half of all bank branches in the Palestinian territories. In telecommunications, two companies-Paltel and Wataniya Mobilecompletely monopolize Palestinian cellular, fixed landlines, and Internet service provision in the West Bank. The first is controlled through a holding company that is dominated by the Masri family and a range of other diaspora investors (mostly from the Gulf), while the second is a subsidiary of a Qatari telecom company. Similar patterns of ownership and control over key Palestinian economic sectors can be seen in real estate, manufacturing and transport, retail, and energy ${ }^{63}$

These characteristics of Palestinian class structure help to illuminate the neoliberal form of state-building under the PNA. As noted earlier, in line with the wider regional trends, the PNA has pursued a clear neoliberal project over the past decade that has been codified in the PRDP and subsequent national development plans. This trajectory is not simply a reflection of policies driven by international financial institutions, but has actually helped constitute the PNA as a principal conduit of wealth transfer to the large, internationalized conglomerates that dominate the Palestinian economy. Affirming the perspective on state theory outlined above, the PNA appears as an institutional form (or social relation) expressing the dominance and interests of these (largely diasporic) capital groups. 
Moreover, this configuration of class and state helps to clarify the social forces that underlie the PNA's incorporation into the structures of the Israeli occupation. Closely tied to the major regional powers in the Arab world, the social class embodied by these large conglomerates remains reliant upon power structures in the Gulf and the regional order constructed over recent decades. Moreover, in Palestine itself, its reproduction as a class is contingent upon the particular form of state-building materialized through the PNA-including the neoliberal policy trajectory and the economic policies that have unfolded through the Oslo process. Palestinian state and class structures are thus intimately linked, with each side of the equation shaping the characteristics of the other.

\section{CONCLUSION: IMPLICATIONS FOR ALTERNATIVE \\ MODELS OF STATE FORMATION}

Before returning to the question of Palestinian state-building in light of these dynamics, it is necessary to briefly discuss how the regional framework has changed following the 2011 Arab uprisings. In their initial phases, the uprisings represented an important moment of popular hope across the region, embodying a rejection of neoliberal authoritarianism and aspirations for a long sought-after transformation in socioeconomic and political rights. In many ways, these uprisings represented the most significant upsurge of popular mobilization since the postwar Arab nationalist struggles; the striking manner in which their political and social forms generalized rapidly across all states in the Middle East indicated a profound challenge to the regional order of the past five decades.

Since this initial phase, Western powers and their regional allies have moved decisively in an attempt to reconstitute state structures and the local bases of support on which their hegemony depends. Despite ongoing struggles, established elites have largely been able to win back political power. Military- and state-supported repression was a critical element in this return to the status quo-seen, for example, in the assassinations of Tunisian opposition leaders Chokri Belaid and Mohammed Brahmi in 2013, and the May 2013 military coup in Egypt. Simultaneously, the devastating repression of the Assad regime in Syria and the ongoing disintegration of the Iraqi state helped to spur the growth of sectarian and Islamic fundamentalist movements across the region, further disrupting the social and political goals initially embodied in the uprisings.

Given the social justice aspirations of the uprisings, it is particularly significant that there has been little change in the near-universal hegemony of the neoliberal development model post-2011. The Deauville Partnership, an initiative launched at the May 2011 G8 Summit in France and led by the major international financial institutions, which promised up to forty billion US dollars in loans and other assistance towards Arab countries "in transition," was premised upon a neoliberal orientation in all its essential elements. ${ }^{64}$ Since that time, both the World Bank 
and IMF have deepened their engagement in the region, rolling out new loan agreements and assistance that are in essential continuity with past programsemphasizing private-sector driven growth, fiscal austerity (particularly subsidy and pension reform), and the liberalization of financial and labor markets. ${ }^{65}$ International actors, notably the EBRD, have also entered the region for the first timemaking explicit the argument that state-building necessarily involves the twinning of liberal democracy and neoliberal economic policy. Indeed, the current socioeconomic and political crises are frequently portrayed by IFIs as an opportunity to extend the policy trajectories of past regimes. As the European Investment Bank noted not long after the overthrow of Ben Ali and Mubarak, "moments of political change can also represent an opportunity to reinforce or improve already existing institutional frameworks." 66

The Gulf states have played a central role in shaping the new political arrangements that emerged in the post-2011 period. This has involved financial and political support to new governments, political movements, and armed groups. The battle to assert regional hegemony has been marked by the surfacing of severe rivalries within the Gulf itself (e.g., between Saudi Arabia and the UAE on one side, and Qatar on the other), which has frequently led to different Gulf states sponsoring opposing forces in neighboring Arab states. Economically the Gulf also remained dominant in the years after the uprisings, with an ever-widening gap emerging between it and the rest of the region from 2011 to 2014 . This differentiation of power and wealth can be attributed to both the ways in which different zones of the Middle East have been inserted into the world market as well as the enduring crises of the region. With the relatively stable emergence of the Gulf states from the global crisis of 2008 and the high oil prices that continued from 2010 to mid-2014, Gulf states were able to accumulate vast quantities of surplus capital. Even following the collapse in oil prices in 2014, the Gulf Cooperation Council states have continued to play a dominant political and economic role in the Arab world. ${ }^{67}$ At the same time, the rest of the region has been faced with the ongoing weakness of major trading partners-particularly the European Unionand the political and social crises of states such as Egypt, Libya, Yemen, Iraq, and Syria. The ensuing regional differentiation is a critical characteristic of the contemporary moment.

Throughout these developments, Israel's integration into the Arab world continues to be an important focus of long-term Western policy-despite the popular Arab antipathy towards this goal. In particular, from 2015 onwards, the increasingly close relationship between Israel, Saudi Arabia, and the UAE has become apparent in joint military exercises, commercial and economic ties-most conspicuously in the security, surveillance, and high tech sectors-as well as open visits of high-ranking political figures. Israel also emerged as one of the earliest endorsers of the Saudi-UAE actions against Qatar in mid-2017, echoing its growing convergence with Saudi Arabia and the UAE on many of the key political 
questions in the region. These developments also set the stage for the Abraham Accords, signed in August 2020, which officially recognized the normalization of economic relations between Israel and the United Arab Emirates and Bahrain.

All of these features of the contemporary moment affirm that the characteristics of class and state formation in Palestine will continue to be shaped by developments at the regional scale. Given this fact, what does the analysis of this chapter say about the possibilities for models of state formation that could encompass the aspirations of Palestinian self-determination? Most significantly, what conditions are necessary for an alternative path that breaks from the current situation under the PNA, and moves towards including the totality of the Palestinian people-not least those that live outside the borders of the West Bank and Gaza Strip?

The first aspect to emphasize in this regard is one of the core premises of this chapter: the importance of not approaching the question of state formation in the abstract-that is, as simply a technocratic question of arranging institutional forms to best meet a checklist of preconceived functions such as authority, legitimacy, and capacity. The character of the state needs to be seen as reflective of social and other power structures that are delineated across various spatial scales. The state is not a neutral apparatus that sits above these structures, but rather a social relation that enables ruling groups to maintain their dominant position vis-à-vis those who are dominated. In this sense, it is imperative to consider, on the one hand, the social forces that underlie existing state arrangements, and, on the other hand, those that may enable alternative models of state-building to emerge. Without assessing these social forces, analyses of state formation that focus simply on a normative "recipe" of institution-building or establish moral criteria for how those states should function tend to abstract the concrete relations of power and thus-inadvertently or not-reinforce those very relations.

In the Palestinian case, this paper has surveyed the critical literature of statebuilding, which correctly highlights the ongoing reality of Israeli occupation and the importance of incorporating the impact of this settler-colonial context into an understanding of the PNA state-building project. It has also, however, argued for the need to situate this project within the wider context of the regional political economy. This includes an appreciation of the ways in which the state system arose in the Middle East, fully located within the global economy, and the more recent changes in regional accumulation patterns that have occurred under the aegis of US power. The significant realignment of the regional political economy through the 1990 s and early 2000 s was driven by a variety of intersecting factors: military conflict and state-building (with Iraq as the principle illustration of this); the widespread adoption of neoliberal policies by all states in the region; the impetus towards deepening regional trade and financial linkages embodied in the various projects promoted by the United States, European Union, and international financial institutions; and the increasing intermeshing of capital ownership across the regional space, typified most sharply in the internationalization of Gulf-based 
capital. All of these emerging features of the regional political economy were profoundly connected with the normalization of Arab relations with the Israeli state. And in this respect, the formation of the PNA and the extension of its state-building project across the West Bank was a central feature of the period.

The internationalization of regional capital-particularly that originating in the Gulf Arab states-is essential to understanding the nature of class formation under the Palestinian National Authority. The class that has emerged as a result of these processes is interiorized within the structures of the PNA state-in-formation, and simultaneously constituted at the regional scale through its ongoing accumulation activities in the Gulf and other neighboring countries. In this sense, Palestinian capital reproduces itself across different spatial scales that cannot be confined to the national "borders"-however ill-defined-that exist within the OPT. Breaking with nationalist methodological perspectives that treat social relations as neatly circumscribed within these borders is thus imperative to a full appreciation of state/class relations in the Palestinian context.

This internationalizing class is a particularly important frame through which to view the Palestinian state-building project as it is currently conceived. It constitutes the primary social base of the PNA within Palestinian society, shaping the character of its policy-making and institution-building at the domestic level. It does so in full interaction with international state-building actors and the structures of the Israeli occupation and thus-in terms of assessing the various social forces at play within the state-building project-needs to be viewed as both a key element of the obduracy of the status quo, as well as a fundamental obstacle to any alternative paths of state formation.

Given this arrangement of social forces, any alternative model of state formation-notably that embodied in a single-state solution-is necessarily premised on a fundamental challenge to the position of current Palestinian elites, particularly those whose accumulation is predicated upon the state/class relations analyzed in this chapter. Any just and progressive alternative model of state formation is thus unlikely to be an elite-driven project, but will take place in opposition to these elites and involve the dismantling and rejection of existing political economy structures in Palestine. It necessitates, in other words, not simply a political change, but must also involve tackling economic inequity and the dominance of the neoliberal paradigm. Moreover, because an alternative path in Palestine needs to occur in tandem with regional change, any full assessment of the prospects of Palestinian state formation is not solely a question of internal Palestinian (or indeed, Israeli) dynamics.

\section{NOTES}

1. Andreas Wimmer and Nina Glick-Schiller, "Methodological Nationalism and Beyond: NationState Building, Migration and the Social Sciences," Global Networks 2, no. 4 (2002): 301-34. 
2. White House Office of the Press Secretary, "President Bush Discusses Importance of Democracy in Middle East: Remarks by the President on Winston Churchill and the War on Terror, Library of Congress, February 4, 2004," https://georgewbush-whitehouse.archives.gov/news/releases /2004/02/20040204-4.html.

3. Toufic Haddad, Palestine Ltd.: Neoliberalism and Nationalism in the Occupied Territory (London: I.B. Tauris, 2016), 25.

4. Mandy Turner, "Building Democracy in Palestine: Liberal Peace Theory and the Election of Hamas,” Democratization 13, no. 5 (2006): 740.

5. Turner, "Building Democracy," 742.

6. Francis Fukuyama, State Building: Governance and World Order in the Twenty-First Century (London: Profile, 2005), 125.

7. World Bank, The State and Peace-Building Fund, https://www.worldbank.org/en/programs /state-and-peace-building-fund/overview, accessed May 2021.

8. See Haddad, Palestine Ltd., for a comprehensive survey.

9. Max Weber, Economy and Society. An Outline of Interpretive Sociology (Berkeley: University of California Press, 1978), 54-55.

10. World Bank, Strengthening Governance: Tackling Corruption. The World Bank Group's Updated Strategy and Implementation Plan (Washington, DC: World Bank, 2012), 9-10.

11. United States Agency for International Development, "Fragile States Strategy," 2005, http:// www.usaid.gov/policy/2005_fragile_states_strategy.pdf, 1.

12. Ad-Hoc Liaison Committee, "Meeting of the Ad Hoc Liaison Committee New York, Chair's Summary," September 18, 2011, United Nations Information System on the Question of Palestine, http://unispal.un.org/UNISPAL.NSF/o/25BBF4BD29E3590485257911004DEo45\#sthash.MQHI6cgs .vP7aIvLy.dpuf; World Bank, The Underpinnings of the Future Palestinian State: Sustainable Growth and Institutions (Washington, DC: World Bank, 2010).

13. Haddad, Palestine Ltd, 63.

14. Turner, "Building Democracy in Palestine," 740.

15. European Council, "Presidency Conclusions: Berlin European Council," March 24 and 25, 1999, United Nations Information System on the Question of Palestine, http://unispal.un.org /UNISPAL.NSF/o/F6ED2F19B37DACCA85256F95007A259F.

16. Palestinian National Authority, Building a Palestinian State: Towards Peace and Prosperity (Paris: PNA, 2007), 18.

17. Keith Dayton, "Speech to the Washington Institute's 2009 Soref Symposium," Washington Institute for Near East Policy, May 7, 2009, www.washingtoninstitute.org/html/pdf/DaytonKeynote.pdf.

18. Numan Kanafani and Samia Al-Botmeh, "The Political Economy of Food Aid to Palestine," The Economics of Peace and Security Journal 3, no. 2 (2008): 39-48; Iyad Riyahi and Nahed Samara, Just Ahead of the Crisis: Policies Designed to Plunge the West Bank into Debt (Birzeit: Centre for Development Studies, Birzeit University, 2014); Firas Jaber and Imad Sayrafi, Lending and Development Policies in the Occupied Palestinian Territory (Birzeit: Centre for Development Studies, Birzeit University, 2014); Samia Al-Botmeh, "Implications of the Kerry Framework: The Jordan Valley," Journal of Palestine Studies 43, no. 3 (2014): 49-51; Mandy Turner, "Peacebuilding as Counterinsurgency in the Occupied Palestinian Territory," Review of International Studies 41, no. 1 (2015): 73-98; Mandy Turner and Omar Shweiki, Decolonizing Palestinian Political Economy: De-development and Beyond (New York: Palgrave-McMillan, 2015); Haddad, Palestine Ltd.; Leila Farsakh, "Palestinian Economic Development: Paradigm Shifts since the First Intifada," Journal of Palestine Studies 45, no. 2 (2016): 55-71; Leila Farsakh, "Undermining Democracy in Palestine: The Politics of International Aid since Oslo," Journal of Palestine Studies 45, no. 4 (2016): 48-63.

19. Mushtaq Khan, "Palestinian State Formation since the Signing of the Oslo Accords," 2009, available at http://eprints.soas.ac.uk/9964/1/Palestinian_State_Formation_since_Oslo_Internet.pdf, 6. 
20. Khan, "Palestinian State Formation," 9.

21. Khan, "Palestinian State Formation," 11.

22. Sara Roy, Failing Peace: Gaza and the Palestinian-Israeli Conflict (London: Pluto Press, 2007); Turner, "Building Democracy in Palestine"; Leila Farsakh, Palestinian Labor Migration to Israel: Labor, Land and Occupation (London: Routledge, 2005).

23. International Crisis Group, "The Meanings of Palestinian Reform," Middle East Briefing, November 12, 2002, 2.

24. Oliver Richmond, "Jekyll or Hyde: What Is Statebuilding Creating? Evidence from the 'Field," Cambridge Review of International Affairs 27, no. 1 (2014): 7.

25. Turner, "Building Democracy in Palestine," 740.

26. Farsakh, "Undermining Democracy in Palestine," 56.

27. Sahar Taghdisi-Rad, The Political Economy of Aid in Palestine: Relieffrom Conflict or Development Delayed? (London: Routledge, 2010), 10-11.

28. Adam Hanieh, "Development as Struggle: Confronting the Reality of Power in Palestine," Journal of Palestine Studies 45, no. 4 (2016): 32-47.

29. Turner and Shweiki, Decolonizing Palestinian Political Economy; Raja Khalidi and Sobhi Samour, "Neoliberalism as Liberation: The Statehood Program and the Remaking of the Palestinian National Movement," Journal of Palestine Studies 40, no. 2 (2011): 6-25.

30. Turner, "Peacebuilding as Counterinsurgency;" Khalidi and Samour, "Neoliberalism as Liberation"; Center for Development Studies, Critical Readings of Development under Colonialism: Towards a Political Economy for Liberation in the Occupied Palestinian Territories (Birzeit: Birzeit University, 2015).

31. Hugo Radice, "The Developmental State under Global Neoliberalism," Third World Quarterly 29, no. 6 (2008): 1,153-74.

32. Radice, "The Developmental State," 1157.

33. Neil Davidson, "The Necessity of Multiple Nation-States for Capital," Rethinking Marxism: A Journal of Economics, Culture and Society 24, no. 1 (2012): 24-46.

34. Raju J. Das, "State Theories: A Critical Analysis," Science and Society 6o, no. 1 (1996): 43.

35. Bertell Ollman, Dance of the Dialectic: Steps in Marx's Method (Urbana: University of Illinois Press, 2003), 202.

36. Fred Block, Revisiting State Theory: Essays in Politics and Post-Industrialism (Philadelphia: Temple University Press, 1987), 21.

37. Radice, "The Developmental State," 1,163.

38. Radice, "The Developmental State," 1,157-58.

39. Greg Albo, "Contesting the 'New Capitalism,"' in Varieties of Capitalism, Varieties of Approaches, edited by David Coates, 63-82 (New York: Palgrave Macmillan, 2005), 74.

40. Simon Bromley, American Hegemony and World Oil: The Industry, the State System and the World Economy (Cambridge: Polity Press, 1991); Timothy Mitchell, Carbon Democracy: Political Power in the Age of Oil (London: Verso, 2011); Adam Hanieh, Capitalism and Class in the Gulf Arab States (New York: Palgrave-MacMillan, 2011).

41. Hanieh, Capitalism and Class; Adam Hanieh, Money, Markets and Monarchies: The GulfCooperation Council and the Political Economy of the Contemporary Middle East (Cambridge: Cambridge University Press, 2018)

42. Gilbert Achcar, The People Want: A Radical Exploration of the Arab Uprising (London: Saqi Books, 2013).

43. Ilan Pappe, The Ethnic Cleansing of Palestine (London: Oneworld Publications, 2006); Tikva Honig-Parnass, The False Prophets of Peace: Liberal Zionism and the Struggle for Palestine (Chicago: Haymarket Books, 2011).

44. Haddad, Palestine Ltd., 43. 
45. Adam Hanieh, Lineages of Revolt: Issues of Contemporary Capitalism in the Middle East (Chicago: Haymarket Press, 2013).

46. Hanieh, Lineages of Revolt, chapter 2.

47. Hanieh, Lineages of Revolt, 34.

48. Warren Christopher, quoted in Waleed Hazbun, Beaches, Ruins, Resorts: The Politics of Tourism in the Arab World (Minneapolis: University of Minnesota Press, 2008), 116.

49. US Embassy of Israel, “Text of Cairo Conference Declaration,” November 14, 1996, www .usembassy-israel.org.il/publish/press/summit/es11115.html.

50. Barbara Kotschwar and Jeffrey J. Schott, Reengaging Egypt: Options for US-Egypt Economic Relations (Washington, DC: Peterson Institute for International Economics, 2010), 20.

51. Office of the US Trade Representative, "Trade Policy Agenda, Section III," 2007, https://ustr .gov/sites/default/files/uploads/reports/2007/asset_upload_file677_10626.pdf, 5.

52. Kotschwar and Schott, Reengaging Egypt, 20.

53. "Speech of Ann Paterson (U.S. Dept. of State) at Egypt-Israel QIZ Lunch in NYC," January 15, 2014, http://www.scribd.com/doc/201534696/Speech-of-Ann-Paterson-U-S-Dept-of-State-at-Egypt -Israel-QIZ-Lunch-in-NYC-Jan-15-2014, 7.

54. Robert Zoellick, "Global Trade and the Middle East: Reawakening a Vibrant Past," speech at the World Economic Forum, Amman, Jordan, June 23, 2003.

55. Rebecca M. Nelson, Mary Jane Bolle, and Shayerah Ilias, U.S. Trade and Investment in the Middle East and North Africa: Overview and Issues for Congress (Washington, DC: Congressional Research Service, 2012), 17.

56. European Commission, The Barcelona Declaration, Five Years On 1995-2000 (Luxembourg: European Communities, 2000), http://www.emwis.org/overview/fol101997/fol221357/barcelona-5yrs _en.pdf/download/1/barcelona-5yrs_en.pdf, 17 .

57. European Commission, The Barcelona Declaration, 17.

58. Association agreements with Israel, Jordan, Morocco, Tunisia, the Palestinian Authority, and Turkey were signed between 1995 and 1997; an association agreement with Egypt was signed in 2004 .

59. Hanieh, Money, Markets and Monarchies.

6o. World Bank, Over the Horizon: A New Levant (Washington, DC: World Bank Group, 2014), http://beta.cmimarseille.org/sites/default/files/Over\%2oThe\%2oHorizon\%2oA\%2oNew\%2oLevant_o .pdf, xix.

61. ANIMA, "Foreign Direct Investment Towards the Med Countries in 2008: Facing the Crisis," Anima Investment Network Study, no. 3, April 20, 2009, https://anima.coop/en/foreign-direct-invest ment-in-the-med-countries-in-2008-facing-the-crisis/, 155.

62. Analysis by author based on stock exchange data and bank lists from the Palestine Monetary Authority.

63. Adam Hanieh, "The Internationalisation of Gulf Capital and Palestinian Class Formation," Capital and Class 35, no. 1 (2011): 81-106. See Hanieh, Lineages of Revolt and Hanieh, Money, Markets and Monarchies for further detail on these ownership structures.

64. Sebastian Moffett, Nathalie Boschat, and William Horobin, "G-8 Pledges \$40 Billion for 'Arab Spring," Wall Street Journal, May 28, 2011, http://online.wsj.com/news/articles/SB1000142405270230 4520804576348792147454956.

65. Adam Hanieh, "Shifting Priorities or Business as Usual? Continuity and Change in the Post2011 IMF and World Bank Engagement with Tunisia, Morocco and Egypt," British Journal of Middle Eastern Studies 42, no. 1 (2015): 119-34.

66. European Investment Bank, FEMIP Study on PPP Legal and Financial Frameworks in the Mediterranean Partner Countries, (Luxembourg: European Investment Bank, 2011): 12.

67. Hanieh, Money, Markets and Monarchies. 


\section{BIBLIOGRAPHY}

Achcar, Gilbert. The People Want. London: Saqi Books, 2013.

Ad-Hoc Liaison Committee, "Meeting of the Ad Hoc Liaison Committee New York, 18 September 2011 Chair's Summary," United Nations Information System on the Question of Palestine, http://unispal.un.org/UNISPAL.NSF/o/25BBF4BD29E3590485257911004D E045\#sthash.MQHI6cgs.vP7aIvLy.dpuf.

Akhtar, Shayerah Ilias, Mary Jane Bolle, and Rebecca M. Nelson. "U.S. Trade and Investment in the Middle East and North Africa: Overview and Issues for Congress." Congressional Research Service, 7-5700, R42153, March 4, 2012, https://fas.org/sgp/crs/misc/R42153 .pdf.

Albo, Greg. "Contesting the 'New Capitalism." In Varieties of Capitalism, Varieties of Approaches, edited by D. Coates, 63-82. New York: Palgrave Macmillan, 2005.

Al-Botmeh, Samia. "Implications of the Kerry Framework: The Jordan Valley." Journal of Palestine Studies 43, no. 3 (Spring 2014): 49-51.

ANIMA. "Foreign Direct Investment towards the Med Countries in 2008: Facing the Crisis." Anima Investment Network Study, no. 3 (April 2009).

Block, Fred. Revisiting State Theory: Essays in Politics and Post-Industrialism. Philadelphia: Temple University Press, 1987.

Bromley, Simon. American Hegemony and World Oil: The Industry, the State System and the World Economy. Cambridge: Polity Press, 1991.

Center for Development Studies. Critical Readings of Development under Colonialism: Towards a Political Economy for Liberation in the Occupied Palestinian Territories. Birzeit: Birzeit University, 2015.

Das, Raju J. "State Theories: A Critical Analysis." Science and Society 6o, no. 1 (1996): 27-57.

Davidson, Neil. “The Necessity of Multiple Nation-States for Capital." Rethinking Marxism: A Journal of Economics, Culture and Society 24, no. 1 (2012): 26-46.

European Commission. The Barcelona Declaration, Five Years On, 1995-20oo, http://www .emwis.org/overview/fol101997/fol221357/barcelona-5yrs_en.pdf/download/1/barcelona -5yrs_en.pdf.

European Council. "Presidency Conclusions: Berlin European Council," 24 and 25 March 1999, United Nations Information System on the Question of Palestine, http://unispal .un.org/UNISPAL.NSF/o/F6ED2F19B37DACCA85256F95007A259F.

European Investment Bank. FEMIP Study on PPP Legal and Financial Frameworks in the Mediterranean Partner Countries. volume 1, May, 2011, https://www.eib.org/attachments /med/ppp-study-volume-1.pdf.

Farsakh, Leila. "Palestinian Economic Development: Paradigm Shifts since the First Intifada." Journal of Palestine Studies 45, no. 2 (2016): 55-71.

- Palestinian Labour Migration to Israel: Labour, Land and Occupation (London: Routledge, 2005

- "Undermining Democracy in Palestine: The Politics of International Aid since Oslo." Journal of Palestine Studies 45, no. 4 (2016): 48-63.

Fukuyama, Francis. State Building: Governance and World Order in the Twenty-First Century. London: Profile, 2005. 
Haddad, Toufic. Palestine Ltd.: Neoliberalism and Nationalism in the Occupied Territory. London: I.B. Tauris, 2016.

Hanieh, Adam. Capitalism and Class in the Gulf Arab States. New York: Palgrave-MacMillan, 2011.

- "Development as Struggle: Confronting the Reality of Power in Palestine." Journal of Palestine Studies 45, no. 4 (2016): 32-47.

- "The Internationalisation of Gulf Capital and Palestinian Class Formation." Capital and Class 35, no. 1 (2011): 81-106.

- Lineages of Revolt: Issues of Contemporary Capitalism in the Middle East. Chicago: Haymarket Press, 2013.

- Money, Markets and Monarchies: The Gulf Cooperation Council and the Political Economy of the Contemporary Middle East. Cambridge: Cambridge University Press, 2018.

—. "Shifting Priorities or Business as Usual? Continuity and Change in the Post-2o11 IMF and World Bank Engagement with Tunisia, Morocco and Egypt." British Journal of Middle Eastern Studies 42, no. 1 (2015): 119-34.

Hazbun, Waleed. Beaches, Ruins, Resorts: The Politics of Tourism in the Arab World. Minneapolis: University of Minnesota Press, 2008.

Honig-Parnass, Tikva. The False Prophets of Peace: Liberal Zionism and the Struggle for Palestine. Chicago: Haymarket Books, 2011.

International Crisis Group. "The Meanings of Palestinian Reform." Middle East Briefing, November 12, 2002.

Jaber, Firas, and Imad Sayrafi. Lending and Development Policies in the Occupied Palestinian Territory. Centre for Development Studies: Birzeit: Birzeit University, 2014.

Kanafani, Numan, and Samia Al-Botmeh. "The Political Economy of Food Aid to Palestine." The Economics of Peace and Security Journal 3, no. 2 (2008): 39-48.

Khalidi, Raja, and Sobhi Samour. "Neoliberalism as Liberation: The Statehood Program and the Remaking of the Palestinian National Movement." Journal of Palestine Studies 40, no. 2 (2011): 6-25.

Khan, Mushtaq. "Palestinian State Formation since the Signing of the Oslo Accords," 2009, available at http://eprints.soas.ac.uk/9964/1/Palestinian_State_Formation_since_Oslo _Internet.pdf.

Kotschwar, Barbara, and Jeffrey J. Schott, Reengaging Egypt: Options for US-Egypt Economic Relations. Washington, DC: Peterson Institute for International Economics, 2010.

Ministry of Planning and Administrative Development, State of Palestine. National Development Plan, 2014-2016. February 23, 2014.

Mitchell, Timothy. Carbon Democracy: Political Power in the Age of Oil. London: Verso, 2011.

Office of the US Trade Representative. “Trade Policy Agenda, Section III." 2007. https://ustr .gov/sites/default/files/uploads/reports/2007/asset_upload_file677_10626.pdf.

Ollman, Bertell. Dance of the Dialectic: Steps in Marx's Method. Urbana: University of Illinois Press, 2003.

Organisation for Economic Co-operation and Development. "Concepts and Dilemmas of State Building in Fragile Situations: From Fragility to Resilience." 2008, http://www .oecd.org/development/incaf/41100930.pdf. 
. "The State's Legitimacy in Fragile Situations: Unpacking Legitimacy," 2010, http:// www.oecd.org/dac/incaf/44794487.pdf.

Palestinian National Authority. "Building a Palestinian State: Towards Peace and Prosperity," December 2007, https://unispal.un.org/pdfs/PRDPFinal.pdf.

Pappe, Ilan. The Ethnic Cleansing of Palestine. London: Oneworld Publications, 2006.

Pfeifer, Karen. "How Tunisia, Morocco, Jordan, and Even Egypt Became IMF Success Stories." Middle East Report, no. 210 (Fall 1999): 23-27.

Radice, Hugo. "The Developmental State under Global Neoliberalism." Third World Quarterly 29, no. 6 (2008): 1,153-74.

Richmond, Oliver. "Jekyll or Hyde: What Is Statebuilding Creating? Evidence from the 'Field." Cambridge Review of International Affairs 27, no. 1 (2014): 1-20.

Riyahi, Iyad, and Nahed Samara. Just Ahead of the Crisis: Policies Designed to Plunge the West Bank into Debt. Birzeit: Centre for Development Studies, Birzeit University, 2014.

Roy, Sara. Failing Peace: Gaza and the Palestinian-Israeli Conflict. London: Pluto Press, 2007.

Taghdisi-Rad, Sahar. The Political Economy of Aid in Palestine: Relieffrom Conflict or Development Delayed? London: Routledge, 2010.

Turner, Mandy. "Building Democracy in Palestine: Liberal Peace Theory and the Election of Hamas." Democratization 13, no. 5 (December 2006): 739-55.

. "Peacebuilding as Counterinsurgency in the Occupied Palestinian Territory." Review of International Studies 41, no. 1 (2015): 73-98.

Turner, Mandy, and Omar Shweiki, eds. Decolonizing Palestinian Political Economy: De-development and Beyond. New York: Palgrave-McMillan, 2015.

US Agency for International Development. "Fragile States Strategy." 2005. http://www.usaid .gov/policy/2005_fragile_states_strategy.pdf.

US Embassy of Israel. "Text of Cairo Conference Declaration." November 14, 1996. www .usembassy-israel.org.il/publish/press/summit/es11115.html.

Weber, Max. Economy and Society. An Outline of Interpretive Sociology. Berkeley: University of California Press, 1978.

Wimmer, Andreas, and Nina Glick-Schiller. "Methodological Nationalism and Beyond: Nation-State Building, Migration and the Social Sciences." Global Networks 2, no. 4 (2002): 301-34.

World Bank. Over the Horizon: A New Levant. Washington, DC: World Bank Group, 2014, https://openknowledge.worldbank.org/handle/10986/20491.

- Strengthening Governance: Tackling Corruption. The World Bank Group's Updated Strategy and Implementation Plan. Washington, DC: World Bank, 2012.

- The Underpinnings of the Future Palestinian State: Sustainable Growth and Institutions. Washington, DC: World Bank, 2010. 